\title{
HUBUNGAN MOTIVASI BELAJAR DENGAN HASIL BELAJAR SISWA PADA MATA PELAJARAN KIMIA DI SMA NEGERI 2 KOTA JAMBI
}

\author{
AFRIANITA SIMATUPANG \\ SMA Negeri 02 Kota Jambi, Provinsi Jambi \\ Email : nitaevira@gmail.com
}

\begin{abstract}
ABSTRAK
Penelitian ini bertujuan untuk: (1) mendeskripsikan dan menjelaskan hubungan antara motivasi belajar dengan hasil belajar kimia siswa. (2) mengetahui dan menjelaskan besarnya koefisien korelasi antara motivasi belajar dengan hasil belajar kimia siswa. Penelitian ini menggunakan pendekatan kuantitatif. Populasi penelitian ini adalah seluruh siswa kelas XI IPA di SMA Negeri 2 Kota Jambi tahun pelajaran 2018/2019 dan sampel penelitian berjumlah 72 orang dengan menggunakan teknik cluster sampling. Data dikumpulkan menggunakan instrumen penelitian berupa kuesioner motivasi belajar yang terdiri dari 20 pernyataan positif dan 15 pernyataan negatif dan data hasil belajar siswa menggunakan nilai Ujian Akhir Semester (UAS) siswa. Hasil penelitian menunjukkan bahwa(1) terdapat hubungan yang positif dan signifikan antara motivasi belajar siswa pada pembelajaran kimia dengan hasil belajar kimia siswa. (2) Besarnya koefisien korelasi yang diperoleh yaitu sebesar 0,391, yang berarti $r$ hitung yang diperoleh lebih besar dibandingkan dengan $r$ tabel yang telah ditentukan pada taraf signifikansi 5\% yaitu 0,229, sehingga Hipotesis Nol (H0) dalam penelitian ini dapat ditolak. Berdasarkan hasil tersebut, dapat disimpulkan bahwa terdapat hubungan yang positif dan signifikan antara motivasi belajar pada mata pelajaran kimia dengan hasil belajar kimia siswa.
\end{abstract}

Kata Kunci: pembelajaran kimia, hasil belajar, motivasi belajar

\section{PENDAHULUAN}

Keberhasilan proses pembelajaran di sekolah dipengaruhi oleh banyak faktor, antara lain guru, siswa, kurikulum, lingkungan belajar, sumber belajar dan lainnya. Guru dan siswa merupakan dua faktor terpenting dalam proses pembelajaran. Pentingnya faktor guru untuk membantu siswa agar dapat belajar sesuai dengan kebutuhan dan minatnya (Oemar, 2009). Pembelajaran adalah suatu sistem dimana di dalamnya terdapat komponen-komponen yang saling berinteraksi dan bekerja sama dalam mencapai tujuan pembelajaran. Belajar memerlukan kesiapan siswa dalam mengikuti pelajaran di kelas maupun belajar secara mandiri di rumah. Berkaitan dengan kesiapan, salah satu hal penting antara lain kesiapan fisik dan mental. Kesiapan mental yang dapat mempengaruhi proses belajar diantaranya adalah intelegensi, minat, bakat, kesiapan, kematangan, perhatian, konsentrasi dan motivasi (Afiana dkk, 2015).

Pembelajaran tidak hanya bersifat intelektual, tetapi juga bersifat emosional. Kegembiraan dapat mempertinggi hasil belajar. Dangkal atau dalamnya hasil belajar sangat bergantung dari beberapa hal, salah satu diantaranya adalah dukungan dari pemakaian media itu sendiri. Untuk itu media sangat diperlukan dalam proses belajar mengajar dengan maksud memberikan variasi dalam mengajar dan lebih banyak memberikan realita dalam mengajar sehingga pengalaman anak lebih konkrit (Mardhiah, 2006). Media yang digunakan guru adalah pelengkap atau pembantu bagi guru dalam mengajar dan membantu siswa memahami materi pelajaran yang disampaikan sehingga memperolah hasil belajar dengan baik, dalam hal ini media mempunyai peranan yang sangat penting dalam pembelajaran. (Mardhiah, 2018). Hasil belajar siswa merupakan salah satu tujuan dari proses pembelajaran di sekolah, untuk itu seorang guru perlu mengetahui, mempelajari beberapa metode mengajar, serta dipraktekkan pada saat mengajar. Untuk menghasilkan prestasi (hasil) belajar siswa yang tinggi, guru dituntut untuk mendidik dan mengajar siswa dengan menggunakan metode pembelajaran yang dibutuhkan dalam proses pembelajaran di kelas. Dapat dikatakan bahwa 
adanya hasil belajar siswa yang tinggi dan berkualitas, dapat dihasilkan dari proses pembelajaran yang berkualitas (Nasution, 2018).

Mata pelajaran kimia merupakan salah satu mata pelajaran yang kurang diminati oleh kebanyakan siswa SMA (Subagia, 2014). Hal ini disebabkan karena kimia dianggap sebagai salah satu mata pelajaran yang sulit, yang kadang-kadang membuat siswa tidak mau belajar kimia lebih lanjut. Kimia sering dianggap salah satu mata pelajaran yang sulit bahkan siswa tidak ingin mempelajarinya lebih lanjut. Hal ini dikarenakan masih banyak siswa yang mengalami kesulitan memahami konsep kimia. Padahal pelajaran kimia erat kaitannya dalam kehidupan sehari-hari dan telah memberikan banyak manfaat bagi manusia (Mudewaran, dkk, 2019).

Konsep kimia yang abstrak membuat siswa kurang termotivasi dan dapat mempengaruhi prestasi kognitif siswa. Kimia merupakan ilmu yang mencari jawaban atas apa, mengapa, dan bagaimana gejala alam yang berkaitan dengan komposisi, struktur dan sifat, perubahan, dinamika, dan energetika zat. Oleh karena itu, mata pelajaran kimia di SMA mempelajari segala sesuatu tentang zat yang meliputi komposisi, struktur dan sifat, perubahan, dinamika, dan energetika zat yang melibatkan keterampilan dan penalaran. Sebanyak dua aspek yang berkaitan dengan kimia yang tidak bisa dipisahkan, yaitu kimia sebagai produk (pengetahuan kimia yang berupa fakta, konsep, prinsip, hukum, dan teori), serta kimia sebagai proses, yaitu kerja ilmiah. Materi pembelajaran kimia merupakan salah satu konsep kimia yang dianggap sulit oleh siswa. Siswa merasa kesulitan dalam membedakan antara larutan penyangga dengan hidrolisis. Materi ini membutuhkan pemahaman konsep dan perhitungan kimia yang baik. (Lubis, dkk, 2015).

Pandangan siswa yang menganggap bahwa pelajaran kimia sulit menyebabkan motivasi siswa dalam belajar kimia tidak ada. Seorang siswa yang tidak termotivasi dengan baik saat pembelajaran akan melakukan kegiatan belajar yang cenderung lebih pasif dibandingkan dengan siswa yang termotivasi dengan baik dalam belajar. Berdasarkan penelitian pendahuluan yang dilakukan di SMA Negeri 2 Kota Jambi, didapatkan bahwa hasil belajar ujian akhir semester (UAS) pada mata pelajaran kimia siswa kelas XI IPA di SMA Negeri 2 Kota Jambi tahun pelajaran 2018/2019 masih rendah. Hal ini terlihat dari jumlah siswa yang memperoleh nilai di atas Kriteria Ketuntasan Minimal (KKM) pada ujian akhir semester hanya 13 siswa dengan persentase 9,02\%, sedangkan 131 siswa lainnya nilai ujian akhir semester yang diperoleh masih di bawah standar kriteria ketuntasan minimal yang telah ditetapkan oleh sekolah. Namun pada saat peneliti melihat proses pembelajaran yang berlangsung, siswa yang memiliki nilai hasil belajar yang rendah memiliki aktivitas belajar yang baik ketika proses pembelajaran berlangsung. Mereka aktif dalam proses pembelajaran dan berani bertanya ketika belum memahami materi yang diberikan.

Setiap proses pembelajaran tentunya diharapkan siswa memperoleh hasil belajar yang baik. Namun pada kenyataannya hasil belajar yang diperoleh siswa tidak selalu baik dan sesuai harapan. Sebagaimana yang menjadi standar baik atau tidaknya hasil belajar atas dasar Kriteria Ketuntasan Minimal (KKM) yang telah ditetapkan sebagai patokan keberhasilan proses pembelajaran. Hal ini harus menjadi perhatian dan bahan evaluasi dalam proses pembelajaran. Hasil belajar siswa yang belum baik menjadi salah satu permasalahan dalam pendidikan. Hasil belajar siswa menunjukkan kemampuan dan kualitas siswa sebagai dampak dari proses pembelajaran yang telah dilaluinya (Nurhasanah, dkk, 2016). Dapat diartikan bahwa hasil belajar merupakan gambaran konkret baik secara tertulis maupun symbol atas pencapaian yang didapatkan pada satu disiplin pengetahuan yang dipelajari. Oleh karena itu hasil belajar dapat didefenisikan sebagai kompetensi dan keterampilan yang dimiliki siswa setelah masa pembelajaran (Molstad, dkk, 2016).

Hasil belajar siswa dipengaruhi oleh dua faktor yaitu faktor internal dan faktor eksternal siswa. Faktor internal siswa diantaranya meliputi gangguan kesehatan, cacat tubuh, faktor psikologis (intelegensi, minat belajar, perhatian, bakat, motivasi, kematangan dan 
kesiapan siswa), dan faktor kelelahan. Sedangkan faktor eksternal yang mempengaruhi proses dan hasil belajar siswa meliputi faktor keluarga, sekolah dan masyarakat (Majid, 2008).

Secara teori, siswa yang memiliki motivasi dalam belajar tentu saja akan aktif dalam pembelajaran. Hal ini dikarenakan motivasi berpangkal dari kata "motif" yang dapat diartikan daya penggerak yang ada di dalam diri seseorang untuk melakukan aktivitas-aktivitas tertentu demi tercapainya suatu tujuan (Sardiman, 2014). Berdasarkan hal inilah, maka dirasakan perlu mengadakan penelitian lebih lanjut untuk mengetahui hubungan antara motivasi belajar pada mata pelajaran kimia dengan hasil belajar yang diperoleh siswa.

\section{METODE PENELITIAN}

Penelitian ini diklasifikasikan ke dalam penelitian kuantitatif dengan mengadopsi rancangan penelitian korelasional. Pada penelitian ini tidak dilakukan perlakuan terhadap subjek penelitian. Peneliti hanya mengukur derajat keterhubungan antara variabel motivasi belajar dan hasil belajar siswa. Penelitian ini melibatkan satu variabel bebas dan satu variabel terikat. Dalam penelitian ini desain penelitian yang digunakan adalah korelasi yaitu meneliti hubungan atau pengaruh sebab akibat antara motivasi belajar dengan hasil belajar kimia siswa. Adapun desain dari penelitian ini adalah seperti gambar berikut:

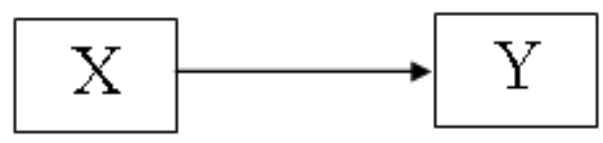

\section{Gambar 1. Desain Penelitian Korelasi}

Keterangan:

Desain Penelitian (diadaptasi dari Sugiyono, 2014)

$\mathrm{X}=$ Motivasi Belajar

$\mathrm{Y} \quad=$ Hasil Belajar Kimia

$\mathrm{r}_{\mathrm{xy}} \quad=$ korelasi antara motivasi belajar dengan hasil belajar

Populasi pada penelitian ini adalah seluruh siswa kelas XI IPA SMA Negeri 2 Kota Jambi tahun pelajaran 2018/2019 yang berjumlah 150 orang yang tersebar ke dalam 4 kelas. Sampel adalah bagian dari jumlah dan karakteristik yang dimiliki oleh populasi tersebut (Sugiyono, 2014). Pada penelitian ini, tekhnik sampling yang digunakan adalah Cluster Sampling. Cluster Sampling merupakan teknik memilih sebuah sampel dari kelompok kelompok unit yang kecil. Teknik ini dipakai karena tidak mungkin dilakukan teknik acak. Pemilihan sample dilakukan dengan memilih 2 kelas yang ada sebagai sampling dengan dilakukan pengundian. Hal ini dilakukan untuk menghemat waktu penelitian, serta dikarenakan populasi yang homogen. Setelah dilakukan pengambilan sampel terpilih siswa kelas XI IPA 1 dan XI IPA 2. Sampel penelitian terdiri dari 2 kelas, dengan jumlah 72 siswa. Lokasi penelitian dilakukan di SMA Negeri 2 Kota Jambi yang terletak di Jl. Pangeran Antasari, Talang Banjar, Kec. Jambi Timur, Kota Jambi, Provinsi Jambi 36121, pada semester genap tahun pelajaran 2018/2019.

Pengumpulan data dilakukan sebanyak 2 tahap yaitu, 1) pengumpulan data motivasi belajar siswa dan 2) pengumpulan data hasil belajar kimia siswa. Instrumen penelitian yang digunakan dalam penelitian ini adalah dengan menggunakan instrumen kuesioner motivasi belajar. Dokumentasi digunakan untuk memperoleh data nama dan nilai hasil belajar yang diperoleh siswa selama proses pembelajaran. Selain itu dokumentasi digunakan sebagai bukti pelaksanaan penelitian, yang mana bukti tersebut berupa foto selama proses penelitian. Penelitian ini menggunakan dua teknik analisis data yaitu analisis deskriptif dan analisis korelasi sederhana. Analisis deskriptif digunakan untuk menggambarkan motivasi belajar dan hasil belajar kimia. Analisis korelasi digunakan untuk menentukan hubungan dan besarnya koefisien korelasi prediktor dengan kriterium. 


\section{HASIL DAN PEMBAHASAN}

Deskripsi umum data hasil penelitian motivasi belajar dan hasil belajar kimia siswa di SMA Negeri 2 Kota Jambi, ditinjau berdasarkan skor tertinggi, skor terendah, standar deviasi, nilai rata-rata (mean), nilai tengah (median), dan nilai terbanyak (modus) dapat dilihat pada tabel 1.

Tabel 1 Deskripsi Umum Motivasi Belajar dan Hasil Belajar

\begin{tabular}{ccc}
\hline Statistik & Motivasi Belajar & Hasil Belajar \\
\hline Valid & 72 & 72 \\
Missing & 0 & 0 \\
Mean & 97.56 & 61.36 \\
Median & 95.50 & 63.00 \\
Modus & 95 & 80 \\
Std. Deviation & 11.455 & 20.898 \\
Range & 49 & 74 \\
Nilai terendah & 75 & 23 \\
Nilai Tertinggi & $\underline{124}$ & $\underline{97}$ \\
\hline
\end{tabular}

Gambaran mengenai karakteristik distribusi skor motivasi belajar, berikut disajikan skor tertinggi, skor terendah, standar deviasi, mean, median, modus. Motivasi belajar memiliki skor tertinggi sebesar 124 dan skor terendah sebesar 75, hasil analisis harga Mean (M) sebesar 97.56, Median (Me) 95,50, modus (Mo) sebesar 95, dan Standar Deviasi (SD) sebesar 11.455. Data variabel hasil belajar diperoleh melalui nilai Ujian Akhir Semester (UAS) hasil belajar siswa dari mata pelajaran kimia dengan jumlah serponden sebanyak 72 siswa. Berdasarkan data variabel yang didapat, diperoleh skor tertinggi sebesar 97 dan skor terendah sebesar 23. Hasil analisis harga Mean (M) sebesar 61.36, Median (Me) sebesar 63.00, Modus (Mo) sebesar 80 dan Standar Deviasi (SD) sebesar 20.898.

Berdasarkan analisis yang dilakukan, besarnya hubungan motivasi belajar dengan hasil belajar kimia yang dihitung dengan menggunakan teknik korelasi product moment dari pearson sebesar 0,391. Hasil $r$ hitung yang diperoleh menunjukkan adanya hubungan yang rendah antara motivasi belajar dengan hasil belajar siswa kelas XI IPA di SMA Negeri 2 Kota Jambi pada mata pelajaran kimia.

Hasil perhitungan yang didapat menunjukkan bahwa $r$ hitung yang didapat yaitu 0,391 lebih besar daripada $r$ tabel pada taraf signifikansi 0,05 yaitu 0,229 dan pada taraf signifikansi $1 \%$ yaitu 0,297. Besarnya $r$ hitung yang didapat menunjukkan bahwa terdapat hubungan antara motivasi belajar kimia siswa dengan hasil belajar kimia, sehingga dapat disimpulkan bahwa H0 dapat ditolak sehingga dapat ditarik kesimpulan terdapat hubungan yang positif dan signifikan antara motivasi belajar yang dimiliki oleh siswa dengan hasil belajar kimia siswa.

\section{Pembahasan}

Penelitian ini bertujuan untuk mengetahui hubungan antara motivasi belajar dengan hasil belajar kimia siswa kelas XI IPA di SMA Negeri 2 Kota Jambi dan besar koefisien korelasi antara motivasi belajar dengan hasil belajar. Motivasi belajar merupakan daya penggerak dalam diri siswa untuk mampu mencapai hasil belajar yang optimal sehingga tujuan yang dikehendaki dalam belajar dapat tercapai. Siswa yang memiliki motivasi yang tinggi dalam belajar akan mampu melaksanakan kegiatan belajar dengan tanggung jawab dan keyakinan penuh bila dibandingkan dengan siswa yang memiliki motivasi belajar yang rendah, sehingga hasil belajar yang dicapai mampu didapat secara optimal.

Hasil penelitian secara deskriptif menunjukkan bahwa, siswa kelas XI IPA di SMA Negeri 2 Kota Jambi memiliki tingkat motivasi belajar yang tinggi pada mata pelajaran kimia, namun hasil belajar yang diperoleh tergolong sedang. Hal ini terlihat dari rerata total skor motivasi belajar yang diperoleh siswa yaitu pada 97,56, sedangkan rerata hasil belajar yang diperoleh oleh siswa pada mata pelajaran kimia menunjukkan hasil yaitu sebesar 61,36. 
Siswa memperoleh hasil belajar yang kurang maksimal disebabkan karena kurang latihan dalam mencari dan memecahkan masalah soal- soal terutama dalam menjawab soalsoal latihan pada LKS, mudah terpengaruh dengan jawaban teman dan tidak ragu-ragu dalam mengikuti pendapat ataupun jawaban dari teman meskipun jawaban atau pendapat temannya belum tentu benar. Siswa kurang latihan dalam mencari dan memecahkan soal- soal terlihat dari jawaban kuesioner siswa pada butir pernyataan no 33. Hasil yang diperoleh $67 \%$ siswa menjawab kadang- kadang senang mencari soal-soal kimia yang sulit di LKS untuk diselesaikan. Pada butir pernyataan no 35 diperoleh hasil $40 \%$ siswa menjawab kadangkadang senang mendapatkan soal-soal baru dan berusaha untuk menjawab dengan benar. Siswa kurang latihan dalam menjawab soal-soal yang terdapat pada LKS, sehingga ketika Ujian Akhir Semester (UAS) menjadi kelabakan dalam menjawab soal-soal yang diberikan oleh guru. Senada dengan Syah (2010:57) menyatakan bahwa latihan menjawab soal-soal sangat bermanfaat dalam proses pembelajaran karena dapat memberikan pengalaman pendidikan bagi para siswa, mampu memantapkan hasil belajar yang diperoleh, penguasaan aspek-aspek perubahan tingkah laku siswa, mampu mengembangkan kemampuan berfikir untuk dapat memecahkan masalah-masalah yang dihadapi baik secara individu maupun kelompok, mampu mambantu cara pembelajaran yang lebih efektif; seperti mengingat, meniru dan otomatisasi jawaban- jawaban, sehingga mampu memaksimalkan tercapainya hasil belajar.

Siswa kurang memiliki rasa percaya diri terhadap jawaban yang dibuat dan lebih bergantung terhadap jawaban dari orang lain. Pernyatan dapat dilihat dari jawaban kuesioner siswa pada butir pernyataan nomor 27 , diperoleh hasil $65 \%$ siswa menjawab mudah terpengaruh dengan jawaban teman. Pada butir pernyataan nomor 28 diperoleh $46 \%$ siswa menjawab tidak ragu-ragu mengikuti pendapat teman ketika mengerjakan ulangan maupun tugas yang diberikan oleh guru. Hal ini sejalan dengan penelitian yang dilakukan oleh Murtiningsih (2017) yang menyatakan bahwa siswa yang tidak memiliki rasa percaya diri, akan sangat susah untuk meyakini kemampuan dan usaha-usaha yang telah dicapainya, sehingga mempengaruhi kualitas hasil belajar siswa yang diperoleh. Senada dengan penelitian yang dilakukan oleh Sari, Sunarno, \& Sarwanto (2018) yang menyatakan bahwa aspek percaya diri siswa memberi sumbangan sebesar 55,28\% dalam mendorong motivasi siswa dalam belajar. Sari, et al. (2018) menyatakan bahwa rasa percaya diri siswa dapat dilihat dari bagaimana siswa dalam menyelesaikan tugas yang diberikan baik secara individu maupun kelompok, menyelesaikan soal-soal dengan percaya diri dan tidak menjiplak pekerjaan teman dan lain sebagainya. Rasa percaya diri yang rendah pada siswa akan mempengaruhi motivasi belajar yang dimiliki oleh siswa tersebut sehingga secara tidak langsung akan mempengaruhi hasil belajar yang diperoleh. Sejalan dengan pendapat Sardiman (2012) menyatakan bahwa dalam kegiatan belajar mengajar, hasil belajar yang diperoleh oleh siswa akan berhasil baik apabila seorang siswa mampu mempertahankan pendapat yang dia miliki, ketika sudah yakin dan dipandang cukup rasional.

Beberapa faktor di atas menjadi penyebab siswa memperoleh hasil belajar yang tidak begitu baik, meskipun rata-rata siswa memiliki motivasi belajar yang tinggi dalam pembelajaran kimia. Hal ini dapat dijadikan pedoman untuk guru, agar siswa tidak hanya sekedar memiliki motivasi yang tinggi dalam belajar tetapi juga harus memperoleh motivasi yang tepat dan optimal didalam belajar sehingga siswa mampu memperoleh atau mencapai tujuan belajar yang maksimal.

Hasil uji analisis yang telah dilakukan menggunakan uji korelasi sederhana dengan bantuan program SPSS PC 16.0 for Windows, menunjukkan bahwa ada korelasi yang positif dan signifikan antara hubungan motivasi belajar dengan hasil belajar kimia siswa kelas XI IPA di SMA Negeri 2 Kota Jambi. Korelasi yang positif dan signifikan terlihat dari nilai $r$ hitung yang didapat lebih besar dari nilai $\mathrm{r}$ tabel pada taraf signifikansi $1 \%$ dan pada taraf signifikansi 5\% yaitu sebesar 0,391 >0,297 >0,229. Maka hipotesis nol (H0) pada penelitian ini ditolak. Jadi ada korelasi yang positif antara motivasi belajar dengan hasil belajar kimia. 
Korelasi yang positif berarti semakin tinggi motivasi belajar yang dimiliki siswa, maka akan semakin baik pula hasil belajar yang diperoleh oleh siswa tersebut. Hasil penelitian ini sejalan dengan penelitian yang dilakukan oleh Rozana Ulfah, K., Santoso, A., \& Utaya, S., (2016), yang menyatakan bahwa ada korelasi positif antara motivasi belajar dengan hasil belajar siswa. Penelitian yang dilakukan oleh Fatimah \& Noviana (2017) yang menyatakan bahwa terdapat hubungan yang positif dan signifikan antara motivasi belajar dengan prestasi belajar kimia di kelas XI IPA SMAN 1 Gedangan.

Secara teoritis, keberhasilan siswa dalam belajar dipengaruhi oleh berbagai faktor yang salah satunya dipengaruhi oleh motivasi dalam belajar. Penelitian Dimyati dan Mudjiono (2013) menyatakan bahwa seseorang yang memiliki motivasi yang tinggi dalam belajar, maka hasil belajar yang akan didapat orang tersebut akan semakin baik. Motivasi belajar yang tinggi tercermin dari ketekunan yang tidak mudah patah dalam mencapai kesuksesan meski dihadang oleh berbagai kesulitan, tidak mudah terjebak pada kegiatan yang bersifat berulang- ulang begitu saja sehingga menjadi kurang kreatif, serta mampu mempertahankan pendapatnya dan senang dalam menyelesaikan masalah- masalah yang ada dan mampu menyelesaikannya. Ketika siswa telah memperoleh motivasi belajar yang tinggi dan tepat, hal ini akan menggiatkan siswa dalam aktivitas belajarnya serta mampu melaksanakan kegiatan belajar dengan penuh keyakinan dan tanggung jawab dibandingkan siswa dengan motivasi belajar yang rendah. Di dalam proses pembelajaran siswa akan menemukan berbagai permasalahan yang dihadapi, sehingga seorang siswa harus memiliki semangat dan motivasi yang tinggi dalam belajar agar mampu mencapai tujuan yang ingin dicapai. Ketika menghadapi suatu permasalahan seorang siswa harus dapat memecahkan masalah yang dihadapinya. Motivasi belajar yang tinggi diharapkan mampu menjadi rekomendasi bagi para guru untuk dapat mengarahkan siswamenjadi pelajar yang aktif dalam proses belajar mengajar, serta mampu memberikan motivasi yang tepat dalam proses pembelajaran, sehingga siswa mampu meraih hasil belajar yang maksimal.

Uno (2012) menyatakan terdapat beberapa teknik untuk memberikan motivasi yang tepat untuk dapat digunakan oleh guru dalam pembelajaran, yaitu: (1) pernyataan penghargaan secara verbal terhadap perilaku yang baik atau hasil belajar siswa yang baik, (2) menggunakan nilai ulangan sebagai pemacu keberhasilan, (3) menimbulkan rasa ingin tahu, (4) memunculkan sesuatu yang tidak diduga, (5) menjadikan tahap dini dalam belajar mudah bagi siswa, (6) menggunakan materi yang dikenal siswa sebagai contoh dalam belajar, (7) menuntut siswa untuk menggunakan hal-hal yang telah dipelajari sebelumnya, (8) menggunakan simulai dan permainan, (9) memberi kesempatan kepada siswa untuk memperlihatkan kemahirannya di depan umum, (10) mengurangi akibat yang tidak menyenangkan dan keterlibatan siswa dalam kegiatan belajar, (11) memperjelas tujuan belajar yang hendak dicapai, (12) merumuskan tujuan-tujuan sementara, (13) memberitahukan hasil kerja yang telah dicapai, (14) membuat suasana persaingan yang sehat di antara para siswa, dan (15) memberikan contoh yang positif, dengan mengurangi kebiasaan memberikan suatu tugas kepada kelas, dan guru meninggalkan kelas untuk melaksanakan pekerjaan lain.

Berdasarkan hasil pembahasan di atas, selain adanya motivasi belajar dalam diri siswa, guru diharapkan untuk dapat memperhatikan variabel- variabel lain yang mampu memengaruhi keberhasilan siswa dalam belajar. Selain motivasi belajar, Dimyati dan Mudjiono (2010) mengemukakan banyak variabel-variabel lain yang mampu memengaruhi keberhasilan siswa dalam mencapai hasil belajar yang baik, yaitu siswa harus memiliki sikap terhadap belajar, konsentrasi belajar, kemampuan mengolah bahan belajar, kemampuan menyimpan perolehan hasil belajar, kemampuan menggali hasil belajar yang tersimpan, kemampuan berprestasi, rasa percaya diri siswa, intelegensi dan keberhasilan belajar siswa, kebiasaan belajar siswa, dan cita-cita siswa 


\section{KESIMPULAN}

Berdasarkan hasil analisis pembahasan yang telah dipaparkan mengenai hubungan motivasi belajar dengan hasil belajar siswa kelas XI IPA di SMA Negeri 2 Kota Jambi, maka dapat ditarik simpulan terdapat hubungan positif dan signifikan antara motivasi belajar siswa pada pembelajaran kimia dengan hasil belajar kimia siswa kelas XI IPA di SMA Negeri 2 Kota Jambi yang dilihat dari besar koefisien korelasi yang diperoleh yaitu sebesar 0,391, yang berarti $r$ hitung yang diperoleh lebih besar dibandingkan dengan $r$ tabel yang telah ditentukan pada taraf signifikansi $1 \%$ dan $5 \%$ yaitu 0,391>0,297> 0,229, menandakan terdapat hubungan yang positif dan signifikan antara motivasi belajar siswa dengan hasil belajar kimia, sehingga hipotesis nol (H0) dalam penelitian ini dapat ditolak. Hasil belajar siswa pada pembelajaran kimia sedang dikarenakan, siswa kurang latihan dalam menjawab soal-soal, kurang memiliki rasa percaya diri terhadap jawaban yang dimilikinya dan lebih bergantung terhadap jawaban dari orang lain.

\section{DAFTAR PUSTAKA}

Aviana, R., \& Hidayah, F. F. (2015). Pengaruh tingkat konsentrasi belajar siswa terhadap daya pemahaman materi pada pembelajaran kimia di SMA Negeri 2 Batang. Jurnal Pendidikan Sains (JPS), 3(1), 30-33.

Dimyati dan Mudjiono. (2010). Belajar dan Pembelajaran. Jakarta: PT Rineka Cipta.

Fatimah Az Zahro, A., \& Noviana Khoirunnisa, R. (2017). "Hubungan Antara Motivasi Belajar dengan Prestasi Belajar Mata Pelajaran Kimia Siswa SMAN 1 Gedangan". Jurnal Psikologi Pendidikan, Vol 4. No. 3.

Lubis, I. R., \& Ikhsan, J. (2015). Pengembangan media pembelajaran kimia berbasis android untuk meningkatkan motivasi belajar dan prestasi kognitif siswa SMA. Jurnal Inovasi Pendidikan IPA, 1(2), 191-201.

Majid, A. (2008). Perencanaan Pembelajaran. Bandung: Remaja Rosdakarya.

Mardhiah, A., \& Akbar, S. A. (2018). Efektivitas media pembelajaran terhadap hasil belajar kimia siswa SMA Negeri 16 Banda Aceh. Lantanida Journal, 6(1), 49-58.

Molstad, C. E., \& Karseth, B. (2016). National Curricula in Norway and Finland: The Role of Learning Outcomes. European Educational Research Journal, 15(3), 329-344.

Muderawan, I. W., Wiratma, I. G. L., \& Nabila, M. Z. (2019). Analisis Faktor-Faktor Penyebab Kesulitan Belajar Siswa Pada Pelajaran Kimia. Jurnal Pendidikan Kimia Indonesia, 3(1), 17-23.

Murtiningsih. (2017). "Pengaruh Motivasi Belajar, Sarana Belajar, dan Percaya Diri Terhadap Hasil Belajar IPS Siswa Penerima BSM (Bantuan Siswa Miskin) SMP Negeri di Surabaya". Jurnal Ekonomi Pendidikan dan Kewirausahaan. Vol. 5., No. 2, Tahun 2017.

Nasution, M. K. (2018). Penggunaan metode pembelajaran dalam peningkatan hasil belajar siswa. Studia Didaktika, 11(01), 9-16.

Nurhasanah, S., \& Sobandi, A. (2016). Minat belajar sebagai determinan hasil belajar siswa. Jurnal Pendidikan Manajemen Perkantoran (JPManper), 1(1), 128-135.

Rozana Ulfah, K., Santoso, A., \& Utaya, S., "Hubungan Motivasi Dengan Hasil Belajar IPS". Jurnal Pendidikan: Teori, Penelitian, dan Pengembangan, Volume: 1, Nomor: 8 bulan Agustus Tahun 2016.

Sardiman, A. M. (2014). Interaksi Dan Motivasi Belajar Mengajar. Jakarta: Rajawali Pers.

Sari, N., Sunarno, W., \& Sarwanto. ((2018). "Analisis Motivasi Belajar Siswa Dalam Pembelajaran Fisika Sekolah Menengah Atas". Jurnal Pendidikan dan Kebudayaan, Vol. 3, Nomor 1, Juni 2018.

Sugiyono. (2014). Statistika Untuk Penelitian. Bandung: Alfabeta.

Syah, D. (2010). Strategi Belajar Mengajar. Jakarta : Diadit Media. 